ENTREPRENEURSHIP AND SUSTAINABILITY ISSUES

ISSN 2345-0282 (online) http://jssidoi.org/jesi/

2020 Volume 8 Number 2 (December)

http://doi.org/10.9770/jesi.2020.8.2(82)

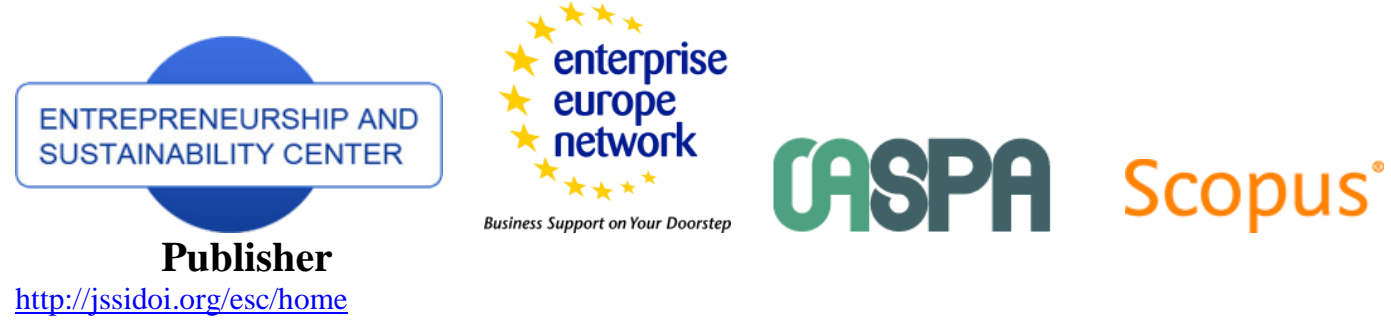

I Clarivate

\title{
DETERMINANTS OF TAX COMPLIANCE: A STUDY ON INDIVIDUAL TAXPAYERS IN INDONESIA
}

\author{
Musthafa Kemal Nasution ${ }^{1}$, Fitri Santi ${ }^{2}$, Husaini ${ }^{3}$, Fadli ${ }^{4}$, Kashan Pirzada ${ }^{5}$ \\ ${ }^{1234}$ Faculty of Economics and Business, University of Bengkulu, Jl. WR. Supratman, Bengkulu 38371 Indonesia \\ ${ }^{5}$ Asian Research Institute for Corporate Governance (AIRCG) and Tunku Puteri Intan Safinaz School of Accountancy, \\ College of Business, Universiti Utara Malaysia, Sintok, Malaysia \\ E-mails: ${ }^{1}$ kemnas73@gmail.com; ${ }^{2}$ fitri_santi@unib.ac.id; ${ }^{3}$ husaini@unib.ac.id; ${ }^{4}$ fadli_abdullah@yahoo.com; \\ 5 kashan@uum.edu.my
}

Received 10 September 2020; accepted 12 November 2020; published 30 December 2020

\begin{abstract}
This study aims to analyze the effect of tax knowledge, tax complexity, and tax justice on taxpayers' trust and tax compliance as well as the differences in tax compliance levels in South Sumatra. The research is explanatory and takes a quantitative approach. The method of data collection used a questionnaire containing the variables and documentation outlined by the study. The research questions were tested using hypothetical compliance scenarios, with 900 registered individual taxpayers from five major cities in South Sumatra as participants. The researchers used confirmatory factor analysis (CFA) with the structural equation modeling (SEM) approach. Results of the research show that (1) tax knowledge has no effect on taxpayers' trust, (2) tax complexity has no effect on taxpayers' trust, (3) tax justice has an effect on taxpayers' trust, (4) tax knowledge has no effect on tax compliance, (5) tax complexity has no effect on tax compliance, (6) tax justice has an effect on tax compliance, (7) taxpayers' trust has an effect on tax compliance, and (8) there were differences in the level of tax compliance after the implementation of the SMS blast program.
\end{abstract}

Keywords: Tax Compliance; Taxpayers' Trust; Tax Knowledge; Tax Complexity; Tax Justice; Individual Taxpayers

Reference to this paper should be made as follows: Nasution, M. K., Santi, F., Husaini, \& Fadli, Pirzada, K. (2020). Determinants of tax compliance: A study on individual taxpayers in Indonesia. Entrepreneurship and Sustainability Issues, 8(2), 1401-1418. http://doi.org/10.9770/jesi.2020.8.2(82)

JEL Classifications: C83, H21, H24

\section{Introduction}

The low level of tax compliance in Indonesia is as crucial as it is in other countries. According to OECD (2017), the Indonesian tax ratio reached $11.8 \%$ in 2015. This is lower than other Southeast Asian countries, such as Malaysia (15.3\%), Singapore (13.6\%) and the Philippines (17\%). This is further explained by Araki and Claus (2014), who classified Indonesia into group of other countries with low levels of tax compliance, such as Cambodia and India. This is significant because Indonesia had the 16th highest gross domestic product (GDP) in 2019 (World Bank, 2019) and is one of the six non-OECD countries with largest economies, along with Brazil, 


\section{ENTREPRENEURSHIP AND SUSTAINABILITY ISSUES}

ISSN 2345-0282 (online) http://jssidoi.org/jesi/

2020 Volume 8 Number 2 (December)

http://doi.org/10.9770/jesi.2020.8.2(82)

Make your research more visible, join the Twitter account of ENTREPRENEURSHIP AND SUSTAINABILITY ISSUES: @Entrepr69728810

Russia, India, China, and South Africa (BRICS) (OECD, 2008). To increase the tax ratio and the nation's income, the Indonesian government must improve tax compliance by exploring the determinants of individual taxpayers' compliance. Chau and Leung (2009) state that "tax compliance is growing international concerns for tax authorities and public policy makers as tax evasion seriously threatens the capacity of government to raise public revenue" (p. 34). Tax compliance is also a main topic in economic psychology. This issue has been analyzed from different perspectives that focus on several aspects of taxpayer behavior. Attitude is measured, social norms are applied, and common theories are explored when people declare their annual tax return (Kirchler, 2007). In Indonesia's case, the number of individual taxpayers dominates all registered taxpayers, at around $90 \%$ of the total. However, their share in terms of tax contribution is still low.

Previous studies have tried to explain the arguments concerning factors that influence tax compliance, but it is unclear whether these studies contribute to the tax system in developing countries because, in some developing countries, local authorities tend to have less power and public trust due to political, social, and economic instability, leading to low tax compliance. On the contrary, some developed countries have demonstrated stronger tax regulation and higher trust, which generate high tax compliance (Bird, Martinez-Vazquez, and Torgler, 2008). The present research names tax compliance as the second endogenous latent variable and applies the theory of planned behavior (TPB) (Ajzen, 1991) to its hypothesis. This research also uses a combination of concepts revealed by Bărbuţă-Mişu (2011) and Alm (2018), who divided factors influencing tax compliance into two groups, namely, economic and noneconomic. This study utilizes several applied theories based on the review of the related literature to analyze the other identified variables: (1) the first endogenous latent variable (taxpayers' trust) and (2) the exogenous latent variables (tax knowledge, tax complexity, and tax justice). This study aims to analyze the effect of tax knowledge, tax complexity, and tax justice on taxpayers' trust and tax compliance as well as the differences in tax-compliance levels in South Sumatra. The researchers selected this region because no tax compliance-related studies have examined it and the rate of individual taxpayers' compliance is still low. Additionally, it may become the benchmark for other regions in Indonesia to increase their tax compliance.

The novelty of this research is the categorization of registered individual taxpayers into two groups: (1) compliant taxpayers (CT) who regularly pay taxes and file an annual tax return and (2) noncompliant taxpayers (NCT). CT consists of paying-filing taxpayers (PFT). NCT is divided into three subgroups: paying-nonfiling taxpayers (PNFT), filing-nonpaying taxpayers (FNPT), and nonpaying-nonfiling taxpayers (NPNFT). Furthermore, none of the previous studies has focused on the differences in tax-compliance levels among individual taxpayers categorized as noncompliant, before and after the implementation of a certain tax scheme. Hence, this study employs a short message service (SMS) blast to test individual taxpayers' compliance levels in South Sumatra. This study contributes to improving tax compliance in South Sumatra and expanding the Indonesian tax base because the focus is shifted from increased tax revenue to new tax revenue generated from NPNFT.

The rest of this paper is organized as follows: a survey of related literature and the development of hypotheses are provided in Section 2. Section 3 describes the research objective and methodology employed in this paper. The results and discussion are reported in Section 4, and Section 5 concludes the paper. 


\section{ENTREPRENEURSHIP AND SUSTAINABILITY ISSUES}

ISSN 2345-0282 (online) http://jssidoi.org/jesi/

2020 Volume 8 Number 2 (December)

http://doi.org/10.9770/jesi.2020.8.2(82)

Make your research more visible, join the Twitter account of ENTREPRENEURSHIP AND SUSTAINABILITY ISSUES: @Entrepr69728810

\section{Literature review}

\subsection{Effect of tax knowledge on taxpayers' trust}

Fahr and Djawadi (2013) explain that tax compliance is considered high in a tax system with low power of authority when complete transparency concerning public expenses is provided and when taxpayers are given options in utilizing the taxes they paid. Fahr and Djawadi (2013) further demonstrate that strong tax authority, reflected from high tax audits, does not guarantee the improvement of tax compliance, even when taxpayers' trust is increased. However, with adequate tax knowledge, taxpayers are more likely to trust the tax authorities, ultimately leading to tax compliance. Palil, Akir, and Ahmad (2013) found that tax compliance is lower among people with less tax education and knowledge. In other words, with proper tax knowledge, taxpayers will be able to decide whether they trust the tax authorities. This emergence of trust will eventually determine the taxpayer's decision to comply with tax obligation. Gitaru (2017) argues that electronic education of taxpayers, print media, taxpayers' education, and the stakeholders' engagement influence tax compliance among small-medium enterprises (SMEs) in Nairobi, Kenya. The sensitivity of stakeholders is positively related to taxpayers' education in calculating correct tax liabilities (Susanto, Pirzada, and Adrianne, 2019) Overall, education influences taxpayers' trust in the tax authorities. This will lead to taxpayers' willingness in paying their taxes voluntarily. Considering these studies, the first hypothesis predicts:

H1: Tax knowledge influences taxpayers' trust in South Sumatra.

\subsection{Effect of tax complexity on taxpayers' trust}

Forest and Sheffrin (2002) state that tax complexity influences taxpayers' trust on tax authorities. Budak and James (2018), who believe that complexity has a significant part in improving the costs of tax compliance, support Forest and Sheffrin's idea. Complexity particularly affects compliance related to complex legislation because complicated legislation makes it costly for taxpayers to comply with their obligations. Saad (2014) proves that tax complexity influences tax compliance. It is caused by the huge amount of paperwork to be completed by taxpayers in New Zealand in complying with their tax obligations. Gambo, Mas'ud, Nasidi, and Oyewole (2014), who investigated tax compliance in 44 African countries, suggest that tax complexity negatively affects taxpayers' trust toward tax authorities. Brainyyah and Rusydi (2016) conducted a study on SME entrepreneurs in Malang, East Java, and discovered that tax complexity has significant and negative correlations with tax compliance behavior. This study indicates that the more complex a tax regulation is, the more ignorant the taxpayers will be. Furthermore, Mahangila (2017), who studied 75 SME entrepreneurs in Dar es Salaam, Tanzania, suggests that tax complexity has an impact on taxpayers' trust toward tax authorities. Based on these studies, the second hypothesis is proposed:

H2: Tax complexity influences taxpayers' trust in South Sumatra.

\subsection{Effect of tax justice on taxpayers' trust}

Benk, Budak, and Cakmak (2012) identify six dimensions of tax fairness, namely, general fairness, tax share and tax burden of middle-income earners, exchange with the government, tax-rate structure, special provisions, and tax system equality and inequality. Benk, Budak, and Cakmak, (2012) further conclude that tax fairness has an impact on taxpayers' trust in Turkey. Gberegbe, Idornigie, and Nkanbia-Davis (2015) explain that taxpayers' perceptions toward tax justice applied by tax authorities affects taxpayers' trust. Faizal and Palil (2015), who 


\section{ENTREPRENEURSHIP AND SUSTAINABILITY ISSUES}

ISSN 2345-0282 (online) http://jssidoi.org/jesi/

2020 Volume 8 Number 2 (December)

http://doi.org/10.9770/jesi.2020.8.2(82)

Make your research more visible, join the Twitter account of ENTREPRENEURSHIP AND SUSTAINABILITY ISSUES: @Entrepr69728810

studied individual taxpayers in Malaysia, reveal that tax fairness perception influences individual taxpayers' trust. This illustrates that the more fairness is perceived by taxpayers, the higher the level of taxpayers' trust will be. Belay and Viswanadham (2016) researched several cities in Amhara Regional State, Ethiopia, and discovered that perceptions of tax fairness have an impact on individual taxpayers' trust. They further explain that there are concerns regarding several aspects of the country's income tax system that need to be improved. Based on the preceding discussions, the third hypothesis is formulated:

H3: Tax justice influences taxpayers' trust in South Sumatra.

\subsection{Effect of tax knowledge on tax compliance}

Newman and Nokhu (2018), who studied several SMEs in Zimbabwe, identified that these SMEs possess basic tax knowledge but no deeper understanding concerning the differences between presumptive taxation and incomebased taxation. However, this result insignificantly affects their noncompliance, meaning tax knowledge influences tax compliance. Newman and Nokhu (2018) further explain that to positively impact tax compliance, tax tariff and corruption issues must be taken seriously. Bernard, Memba, and Oluoch (2018) conducted a study on investors in export processing zones (EPZs) in Kenya and advised that tax knowledge has a close relationship with taxpayers' ability to understand tax rules and regulations as well as their willingness to comply with them. A company with employees trained in taxation matters is likely to voluntarily fulfill their tax obligations based on applied tax rules and regulations. Due to these findings, the fourth hypothesis is as follows:

H4: Tax knowledge influences tax compliance in South Sumatra.

\subsection{Effect of tax complexity on tax compliance}

Krause (2000) proves that uncertainty, ignorance, and burdensome documentation requirements prevent some taxpayers from taking advantage of legitimate tax rebates and deductions, while others find opportunities to avoid taxes in such ambiguous provisions. Complexity has undermined the ability of Internal Revenue Service (IRS) ability to distinguish between intended tax avoidance and honest misinterpretation regarding tax codes and planning Rudyanto and Pirzada, 2020). McKerchar (2005), who surveyed tax agents in Australia, discovered that these agents disagree with the increased complexity of tax laws Richardson (2006), in his research of 45 countries, suggests that complexity is the main driver of noncompliance besides education, source of income, justice, and tax morale. His findings are consistent with that of Cox and Eger III (2006) who believe that complexity leads to misdirection of objectives of the tax agency an increased opportunity for noncompliance. Similarly, Kirchler, Niemirowski, and Wearing (2006) argue that the possibilility of compliance is higher when tax laws are considered less complex. These thoughts lead to the fifth hypothesis:

H5: Tax complexity influences tax compliance in South Sumatra.

\subsection{Effect of tax justice on tax compliance}

Musthapha (2010) performed a study in Nigeria and believes that two out of five dimensions of tax justice, namely, exchange with government and special provisions, affect tax compliance. Similarly, Mukasa (2011) states that an increase in tax justice will lead to the improvement of tax compliance. Gberegbe and Umoren (2017) claim that distributive justice, procedural justice, retributive justice, and perceptions of tax justice affect individual taxpayers' compliance in Rivers State, Nigeria. Olaoye, Ayeni-Agbaje, and Alaran-Ajewole (2017) studied block 


\section{ENTREPRENEURSHIP AND SUSTAINABILITY ISSUES}

ISSN 2345-0282 (online) http://jssidoi.org/jesi/

2020 Volume 8 Number 2 (December)

http://doi.org/10.9770/jesi.2020.8.2(82)

Make your research more visible, join the Twitter account of ENTREPRENEURSHIP AND SUSTAINABILITY ISSUES: @Entrepr69728810

molding firms in Ekiti Province, Nigeria, and point out that tax knowledge has a higher tendency to promote tax compliance than tax administration. Furthermore, Sidik, Zandi, and Ruhoma (2019), who researched individual taxpayers in Libya, state that tax justice influences tax compliance. They believe that public perception of fairness depends on how they perceive tax system to be fair or not. These findings lead to the next hypothesis:

H6: Tax justice influences tax compliance in South Sumatra.

\subsection{Effect of taxpayers' trust on tax compliance}

Wahl, Kastlunger, and Kirchler (2010) discovered that power and trust have a positive impact on tax payment. Dependable and reliable tax authorities could increase tax compliance voluntarily or by law enforcement. Kogler et al. (2013) and Muehlbacher, Kirchler, and Schwarzenberger (2011) revealed similar findings, suggesting that trust in tax authorities increases voluntary tax compliance. Additionally, Bornman (2015) proposes that perceptions of fairness, treatment of authorities, norms and attitudes, and subjective tax knowledge are the main factors determining trust in tax authorities. However, several studies use limited descriptors when measuring this relationship. Bornman (2015) further suggests that standard survey instrument need to be developed to measure this perception. Based on these studies, the seventh hypothesis is proposed:

H7: Taxpayers' trust influences tax compliance in South Sumatra.

\subsection{Differences in taxpayers' compliance levels}

Najah (2008) and Husaini, Pirzada, and Saiful (2020) argues that there is no difference in corporate taxpayers' compliance levels before and after the enactment of a tax audit. Komalasari and Nasih (2010) tested the influence of taxpayers' reported income toward the level of their compliance and found that there was no significant difference in the level of taxpayer compliance whether a $15 \%$ or $30 \%$ tax tariff was imposed. Fajarwati, Kertahadi, and Kurniawan (2004) conducted a study in several tax offices in Malang Raya, East Java and found that there was a significant difference between the degrees of tax compliance before and after the implementation of a tax modernization program. These studies explain the differences in taxpayers' compliance levels before and after the implementation of tax-related schemes. Accordingly, this study applies a tax program called an SMS blast to test the compliance levels in South Sumatra. This leads to the eighth hypothesis:

H8: There will be differences in taxpayers' compliance levels before and after the implementation of the SMS blast program.

\section{Research objective and methodology}

\subsection{Design, variables, measurements, and sources}

This research is explanatory with a quantitative approach. Three main objectives were achieved through this study. The first objective is a description of taxpayers' trust as the first endogenous latent variable (Y1); tax compliance as the second endogenous latent variable (Y2); and tax knowledge (X1), tax complexity (X2), and tax justice (X3) as exogenous latent variables (X). The second is the effect of the exogenous latent variables on Y1 and Y2 and the influence of Y1 on Y2. The third objective is to identify the differences in tax compliance among individual taxpayers who fall into the noncompliant category consisting of PNFTs, NPFTs, and NPNFTs. 
Make your research more visible, join the Twitter account of ENTREPRENEURSHIP AND SUSTAINABILITY ISSUES: @Entrepr69728810

\subsection{Population, sample, data collection, and method of analysis}

The population of this study includes all individual income taxpayers registered in tax offices in the five provinces of South Sumatra, including Jambi, South Sumatra, Bengkulu, Lampung, and the Bangka Belitung Islands (see Table 1). The study used representative sampling to reflect the characteristics of the larger population. Research questions were tested using hypothetical compliance scenarios with 900 registered individual taxpayers from five major cities in South Sumatra as participants. The determination of the sampling method was based on the idea that "the number of samples in the SEM study was 5-10 times the number of indicators" (Hair et al., 2014, p. 615). In this study, the multiplier factor of 10 is used to provide a more detailed and accurate picture of the five variables studied. With a total of 78 indicators, the total sample was 780 people. The sample size was increased to 900 people to anticipate insufficient or incomplete data. In practice, out of five tax offices, 180 samples of individual taxpayers were determined in each province and divided into two groups, consisting of 90 employees and 90 nonemployees. The characteristics of the respondents include gender, age, education, type of employment, and duration as taxpayer (see Table 2).

Table 1. Research Population

\begin{tabular}{|c|c|c|c|c|}
\hline \multirow{2}{*}{ No. } & \multirow{2}{*}{ Provinces } & \multicolumn{2}{|c|}{ Registered Individual Taxpayers } & \multirow{2}{*}{ Subtotal } \\
\hline & & Employees & Nonemployees & \\
\hline 1 & Jambi & 33,286 & 17,823 & 51,109 \\
\hline 2 & South Sumatra & 58,976 & 29,632 & 88,608 \\
\hline 3 & Bengkulu & 31,717 & 15,898 & 47,615 \\
\hline 4 & Lampung & 52,294 & 27,118 & 79,412 \\
\hline 5 & Bangka Belitung Islands & 13,265 & 7,096 & 20,361 \\
\hline & Total & 189,538 & 97,567 & 287,105 \\
\hline
\end{tabular}

Source: Indonesian Directorate General of Taxes (2018)

Table 2. Characteristics of Research Respondents

\begin{tabular}{|l|l|c|c|}
\hline \multirow{2}{*}{ Characteristics } & \multicolumn{1}{|c|}{ Items } & Number of respondents & $\begin{array}{c}\text { Percentage } \\
(\%)\end{array}$ \\
\hline \multirow{4}{*}{ Gender } & Male & 547 & 70.13 \\
\cline { 2 - 4 } & Female & 233 & 29.87 \\
\hline \multirow{5}{*}{ Age } & $17-25$ years & 3 & 1.18 \\
\cline { 2 - 4 } & $26-35$ years & 72 & 28.23 \\
\cline { 2 - 4 } & $36-45$ years & 40 & 15.67 \\
\cline { 2 - 4 } & $46-55$ years & 140 & 54.90 \\
\hline \multirow{5}{*}{ Education } & High school graduate & 78 & 10.00 \\
\cline { 2 - 4 } & Tertiary education (Grade 1-3) & 141 & 18.08 \\
\cline { 2 - 4 } & Bachelor' degree & 492 & 63.08 \\
\cline { 2 - 4 } & Master's degree & 53 & 6.79 \\
\cline { 2 - 4 } & Doctoral degree & 16 & 2.05 \\
\hline
\end{tabular}


ENTREPRENEURSHIP AND SUSTAINABILITY ISSUES

ISSN 2345-0282 (online) http://jssidoi.org/jesi/ 2020 Volume 8 Number 2 (December)

http://doi.org/10.9770/jesi.2020.8.2(82)

Make your research more visible, join the Twitter account of ENTREPRENEURSHIP AND SUSTAINABILITY ISSUES: @Entrepr69728810

\begin{tabular}{|l|l|l|l|}
\hline \multirow{3}{*}{$\begin{array}{l}\text { Type of } \\
\text { employment }\end{array}$} & $\begin{array}{c}\text { Employee a. Civil servant } \\
\text { b. Private }\end{array}$ & 195 & 25.00 \\
\cline { 2 - 4 } & Nonemployee & 195 & 25.00 \\
\hline \multirow{3}{*}{$\begin{array}{l}\text { Duration as } \\
\text { taxpayer }\end{array}$} & $1-5$ years & 390 & 50.00 \\
\cline { 2 - 4 } & $5-10$ years & 434 & 15.29 \\
\cline { 2 - 4 } & $>10$ years & 207 & 52.55 \\
\hline
\end{tabular}

Registered taxpayers in South Sumatra are dominated by men (70.13\%), age 46-55 (54.90\%) with undergraduate qualifications $(63.08 \%)$.

Data collection used a questionnaire containing the latent variables and documentation. The data was then processed using a Likert scale. of the data was analyzed using a quantitative approach to test the effect of the exogenous latent variables $(\mathrm{X} 1, \mathrm{X} 2, \mathrm{X} 3)$ on the first endogenous latent variable $(\mathrm{Y} 1)$ and the second endogenous latent variable (Y2) and to test the effect of Y1 on Y2. The quantitative analysis also examines the differences in compliance levels of noncompliant taxpayers (NCT), who are divided into three subgroups: paying-nonfiling taxpayers (PNFT), filing-nonpaying taxpayers (FNPT), and nonpaying-nonfiling taxpayers (NPNFT). The analysis method uses confirmatory factor analysis (CFA) with the structural equation modeling (SEM) approach. A statistical program called a linear structural relationship (LISREL) was applied to estimate SEM. Other statistical tools included statistical package for the social sciences (SPSS) to perform descriptive statistics, a validity test, a reliability test, and a Z-test. Based on the analyses of previous studies related to tax compliance, trust, tax knowledge, tax complexity, and tax justice, a research framework as seen in Figure 1 was developed.

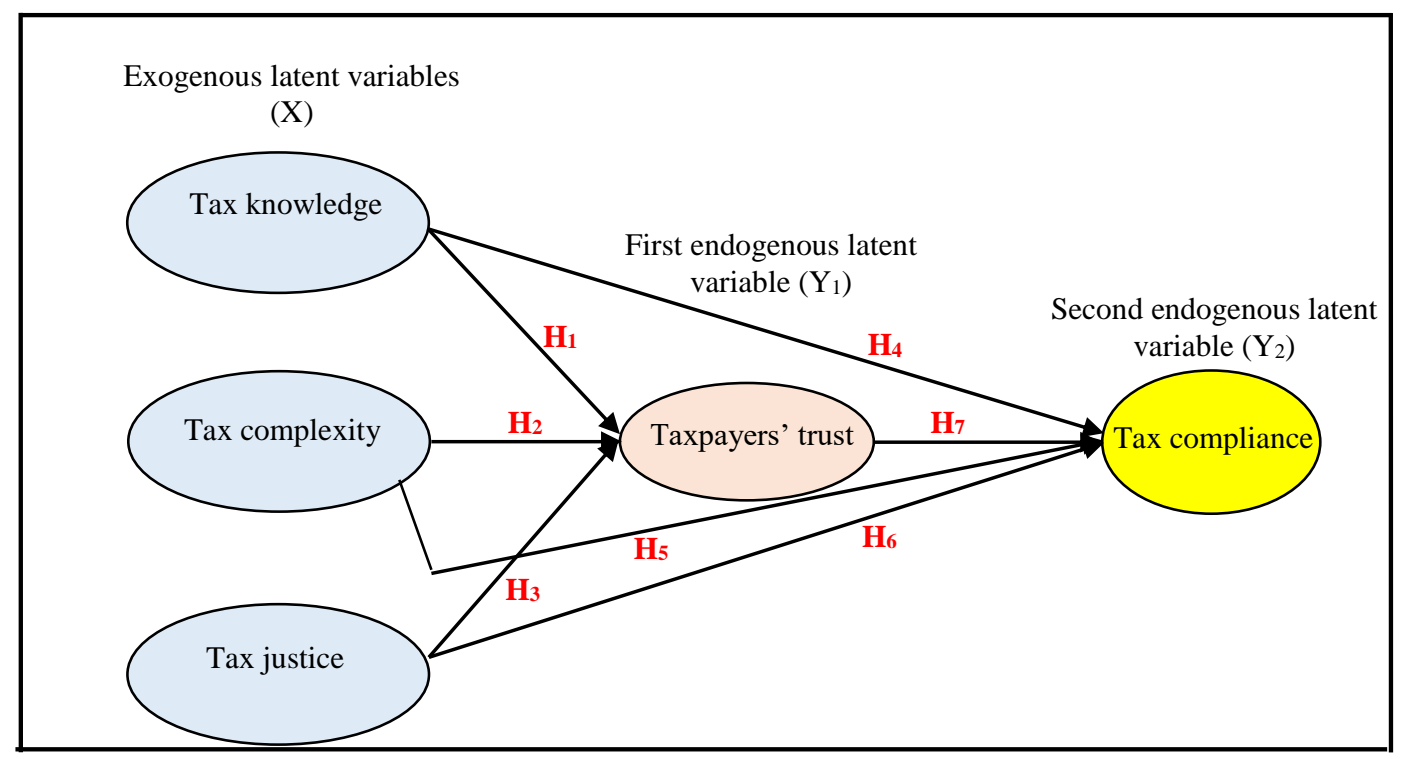

Figure 1. Conceptual Framework

Sources: Tax compliance: Alm (2018); Bărbuţă-Mişu (2011); Taxpayers' trust: Bornman (2015); Tax knowledge: Asrinanda \& Diantimala (2018); Istiqamah et al. (2018); Saad (2014); Tax complexity: AICPA (1992);

Cox \& Eger III (2006); McCaffery (1990); Pau et al. (2007); Richardson \& Sawyer (1998); Saw \& Sawyer (2010);

Tax justice: Colquitt (2001); Farrar et al. (2013); Gberegbe et al. (2015); Kirchler et al. (2014) 
Make your research more visible, join the Twitter account of ENTREPRENEURSHIP AND SUSTAINABILITY ISSUES: @Entrepr69728810

\subsection{Validity and reliability test}

The validity test is a measure of the accuracy of the instruments used in the study (Linn and Grondlund, 2000; Stewart, 2009), while a reliability test shows the number of measurement errors in a test (Tavakol and Dennick, 2011 , p. 53). Reliability and validity are concepts used to evaluate the quality of research. They indicate how well a method, technique, or test measure something. This study employs these two tests to measure the accuracy and consistency of questionnaire items in explaining indicators of each research variable. Hair, Black, Babin and Anderson (2010) suggest that an item is considered valid if it has a factor loading value $>0.6$, while Nunnally and Bernstein (1994) point out that data is reliable if Cronbach's alpha value is $>0.7$. The test results are shown in Table 3.

Table 3. Results of Validity and Reliability Test

\begin{tabular}{|c|l|c|c|c|c|}
\hline No. & \multicolumn{1}{|c|}{ Research variables } & AVE value & Result & $\begin{array}{c}\text { Cronbach's } \\
\text { alpha }\end{array}$ & Result \\
\hline 1 & Tax compliance & 0.76 & Valid & 0.793 & Reliable \\
\hline 2 & Taxpayers' trust & 0.73 & Valid & 0.746 & Reliable \\
\hline 3 & Tax knowledge & 0.76 & Valid & 0.711 & Reliable \\
\hline 4 & Tax complexity & 0.74 & Valid & 0.737 & Reliable \\
\hline 5 & Tax justice & 0.73 & Valid & 0.752 & Reliable \\
\hline
\end{tabular}

Research variables with a value of AVE $>0.6$ indicate there is sufficient convergence for each variable. Cronbach's alpha value is greater than 0.7 , meaning all five variables are reliable for further processing.

\section{Results and discussion}

\subsection{Descriptive statistics}

Table 4 shows that the number of respondents is 780 people and tax compliance had an average value of 298.32 (the lowest value). This indicates that, compared to other variables, tax compliance has the lowest preference among respondents. Taxpayers' trust had an average value of 309.71. Tax knowledge had an average value of 339.50. Tax complexity had an average value of 343.46, and tax justice had an average value of 344.29 (the highest value).

Table 4. Descriptive Statistics Results

\begin{tabular}{|c|l|c|c|c|c|}
\hline No. & \multicolumn{1}{|c|}{ Research variables } & $\mathrm{n}$ & Maximum & Minimum & Mean \\
\hline 1 & Tax compliance & 780 & 615 & 19 & 298.32 \\
\hline 2 & Taxpayers' trust & 780 & 627 & 9 & 309.71 \\
\hline 3 & Tax knowledge & 780 & 688 & 9 & 339.50 \\
\hline 4 & Tax complexity & 780 & 689 & 3 & 343.46 \\
\hline 5 & Tax justice & 780 & 694 & 6 & 344.29 \\
\hline
\end{tabular}

The amount of data to be studied is 780 samples. The tax compliance variable has a mean value of 298.32, meaning an average of 298 individual taxpayers in South Sumatra show preference for tax compliance. 
ENTREPRENEURSHIP AND SUSTAINABILITY ISSUES

ISSN 2345-0282 (online) http://jssidoi.org/jesi/

2020 Volume 8 Number 2 (December)

http://doi.org/10.9770/jesi.2020.8.2(82)

Make your research more visible, join the Twitter account of ENTREPRENEURSHIP AND SUSTAINABILITY ISSUES: @Entrepr69728810

\subsection{Confirmatory factor analysis}

This study utilizes confirmatory factor analysis (CFA) with the SEM approach to analyze the effect of the exogenous latent variables on Y1 and Y2 and the influence of Y1 on Y2. The analysis tool uses a computer-based application program, namely, a linear structural relationship (LISREL). The stages of CFA are as follows (Hair et al., 2010, p. 628):

\subsubsection{Development of theory-based model}

The research model was based on the theory of planned behavior (TPB) (Ajzen, 1991) and a combination of concepts by Bărbuţă-Mişu (2011) and Alm (2018), who place factors influencing tax compliance into two groups, namely, economic and noneconomic. TPB suggests that a person's motivation to perform a certain behavior is also influenced by the individual's perception of how easy or difficult the behavior is. This justifies the need to expand the model to understand other factors that influence tax compliance. This theory-based model consists of five variables, including taxpayers' trust as the first endogenous latent variable (Y1), tax compliance as the second endogenous latent variable (Y2), and tax knowledge, tax complexity and tax justice as exogenous latent variables (X1-X3). The model developed in this study is illustrated in Figure 1.

\subsubsection{Path diagram development}

The path diagram aims to predict the causal relationship between predetermined variables and tests the contribution of each exogenous latent variable to Y1 and Y2 and the contribution of Y1 to Y2 (the test result is not presented in this paper).

\subsubsection{Conversion of path diagram into equations}

The next step after the theoretical model is developed and depicted in a path diagram is to convert the model into a series of equations, which include:

- A structural equation, which aims to determine the causal relationship between various variables. This study produces a structural equation as follows:

Tax Compliance $($ TCO $)=$ Taxpayers' Trust $($ TPT $)+$ Tax Knowledge $(T K)+$ Tax Complexity $(T C)+$ Tax Justice $(T J)+$ error

- The measurement model equation, which only involves the indicators of the variable gauges. The measurement model uses the equation $x=\lambda \xi+e$

\subsubsection{Selection of input matrix and estimation technique}

The input matrix is used to test the causality between variables. The input matrix used in this study is the covariance matrix. The estimation technique is the maximum likelihood estimation method (Hair et al., 2010, p. 631). This technique is carried out in stages by estimating the measurement model with CFA, which aims to determine the suitability of the model and the causality relationship that is built. CFA analysis in this study is carried out in two forms, namely, CFA for exogenous latent variables and for endogenous latent variables. The test results of the exogenous latent variables confirmatory factor model are shown in Table 5. 


\section{ENTREPRENEURSHIP AND SUSTAINABILITY ISSUES}

ISSN 2345-0282 (online) http://jssidoi.org/jesi/ 2020 Volume 8 Number 2 (December)

http://doi.org/10.9770/jesi.2020.8.2(82)

Make your research more visible, join the Twitter account of ENTREPRENEURSHIP AND SUSTAINABILITY ISSUES: @Entrepr69728810

Table 5. Exogenous Latent Variables Confirmatory Factor Model Test Results

\begin{tabular}{|l|c|c|c|}
\hline \multicolumn{1}{|c|}{$\begin{array}{c}\text { Goodness of fit } \\
\text { indices }\end{array}$} & Cut-off value & Results & $\begin{array}{c}\text { Model } \\
\text { evaluation }\end{array}$ \\
\hline Chi-square & $\chi^{2}$ dengan DF $=83 ;$ P: $5 \%=91,273$ & 83.731 & Good \\
\hline Probalility & $\geq 0.05$ & 0.066 & Good \\
\hline CMIN/DF & $<2.00$ & 1.748 & Good \\
\hline GFI & $\geq 0.90$ & 0.911 & Good \\
\hline AGFI & $\geq 0.90$ & 0.929 & Good \\
\hline TLI & $\geq 0.95$ & 0.965 & Good \\
\hline CFI & $\leq 0.95$ & 0.979 & Good \\
\hline RMSEA & $\leq 0.08$ & 0.073 & Good \\
\hline
\end{tabular}

The exogenous latent variable confirmatory model is feasible to be tested at the full-model stage. This is indicated by the value of the calculation results that meet the criteria of a decent model based on various parameters of the feasible model (goodness of fit indices).

Table 5 illustrates that all the parameter values obtained meet the specified cut-off value. The results of the calculation show that each of the forming indicators of each exogenous latent variable meet the criteria, indicated by the critical value $(\mathrm{CR})$, which is greater than 2.58 with probability $(\mathrm{P})$ less than 0.01 . Conversely, there is no specific variable that influences the second endogenous latent variable (tax compliance). Therefore, a confirmatory analysis of the second endogenous latent variable is not applied in this study.

\subsubsection{Structural equation modeling analysis}

Structural equation modeling (SEM) consists of two types: (1) SEM with a covariance-based approach, in which the statistical tools are AMOS/LISREL, and (2) SEM with a variant/component-based approach (Chin, 1998; Fornell and Bookstein, 1982). This study employs LISREL because the sample is more than 500 people. The results of data processing for SEM analysis in the full model are presented in Figure 2. 
Make your research more visible, join the Twitter account of ENTREPRENEURSHIP AND SUSTAINABILITY ISSUES: @Entrepr69728810

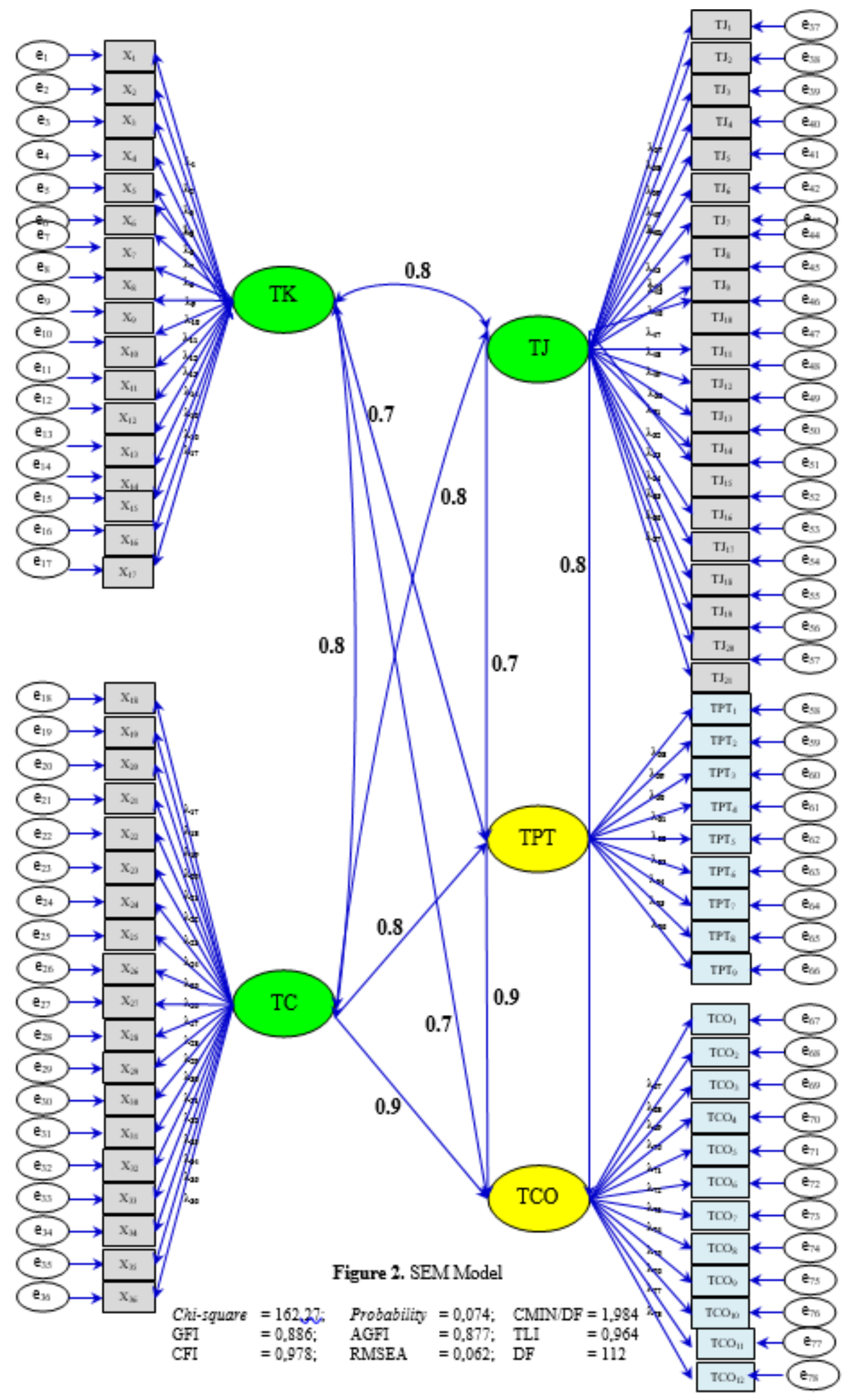




\section{ENTREPRENEURSHIP AND SUSTAINABILITY ISSUES}

ISSN 2345-0282 (online) http://jssidoi.org/jesi/

2020 Volume 8 Number 2 (December)

http://doi.org/10.9770/jesi.2020.8.2(82)

Make your research more visible, join the Twitter account of ENTREPRENEURSHIP AND SUSTAINABILITY ISSUES: @Entrepr69728810

Figure 2 shows that the full-model analysis meets the fit criteria. This is indicated by the value of the calculation that meets the eligibility criteria for the full model. The test results in the full-model analysis are also converted into tabular form as seen in Table 6.

Table 6. Full-Model Test Results

\begin{tabular}{|l|c|r|c|}
\hline \multicolumn{1}{|c|}{$\begin{array}{c}\text { Goodness of fit } \\
\text { indices }\end{array}$} & Cut-off value & Results & $\begin{array}{c}\text { Model } \\
\text { evaluation }\end{array}$ \\
\hline Chi-square & $\chi 2$ dengan DF $=112 ;$ P: $5 \%=168.800$ & 162.271 & Good \\
\hline Probalility & $\geq 0.05$ & 0.089 & Good \\
\hline CMIN/DF & $<2.00$ & 1.984 & Good \\
\hline GFI & $\geq 0.90$ & 0.886 & Good \\
\hline AGFI & $\geq 0.90$ & 0.877 & Good \\
\hline TLI & $\geq 0.95$ & 0.963 & Good \\
\hline CFI & $\leq 0.95$ & 0.978 & Good \\
\hline RMSEA & $\leq 0.08$ & 0.062 & Good \\
\hline
\end{tabular}

The results of the chi-square test calculation on the full model show that the chi-square value of 162.271 is smaller than the chi-square table for 112 degrees of freedom at a significant level $(\rho) 5 \%$ of 168.800 .

Table 6 shows that all parameter values obtained meet the specified cut-off value. Therefore, it can be concluded that the exogenous latent variables meet the criteria for the fit model (goodness of fit indices). Based on these results, all exogenous latent variables can be processed with the full model. SEM results testing is then carried out through the calculation of full-model regression weights. The calculation results show that of the seven hypotheses tested, there are four influences with a CR value smaller than 2.58 and a $\mathrm{P}$ value greater than 0.01 , namely, the effect of tax knowledge on taxpayers' trust, the influence of tax knowledge on tax compliance, the effect of tax complexity on taxpayers' trust, and the effect of tax complexity on tax compliance. Based on these results, these four hypotheses are rejected. In conclusion, only three of the seven hypotheses that use CFA with the SEM approach are accepted.

\subsubsection{Evaluate the criteria for goodness of fit}

Goodness of fit evaluation aims to assess how well the research model is being developed. One way is to test the normality of the data. The data normality test seeks to test whether the regression model has normal data distribution by using the Skewness-Kurtosis test. The values of Z-Skewness and Z-Kurtosis are shown in Table 7.

Table 7. Results of Data Normality Test

\begin{tabular}{|l|c|c|c|c|c|}
\hline \multicolumn{1}{|c|}{ Observed values } & TCO & TPT & TK & TC & TJ \\
\hline Z-Skewness & -1.723 & -1.837 & 1.542 & 1.976 & 1.612 \\
\hline Z-Kurtosis & 1.961 & -1.488 & -1.863 & 1.265 & 1.070 \\
\hline
\end{tabular}

Table 7 shows that none of the tested variables has Z-Skewness and Z-Kurtosis values smaller than -2.58 and greater than +2.58 . Based on these results, it can be concluded that the data for the five research variables were normally distributed. 


\section{ENTREPRENEURSHIP AND SUSTAINABILITY ISSUES}

ISSN 2345-0282 (online) http://jssidoi.org/jesi/

2020 Volume 8 Number 2 (December)

http://doi.org/10.9770/jesi.2020.8.2(82)

Make your research more visible, join the Twitter account of ENTREPRENEURSHIP AND SUSTAINABILITY ISSUES: @Entrepr69728810

\subsubsection{Model interpretation and modification}

A good model has a small standard residual covariance value. The standard residual covariance allowed is +2.58 . These results show that the standard residual covariance exceeds +2.58 in 12 factors. The 12 factors include $x 3$ (bachelor degree), x7 (tax course), x8 (comparative tax study), x17 (self-employed), x23 (difficulty calculating taxable income), x28 (online completion of tax registration), x34 (overly long sentences), x41 (bias), x48 (appropriateness), x49 (timeliness), x53 (taxpayers' technical competency) and x65 (social norms). Based on these results, data modification of the full model is not necessary because only a few indicators exceed +2.58 .

\subsubsection{Hypotheses testing}

Results of the research show that the first hypothesis (H1) has a critical ratio (CR) value of $2.467<2.58$ and probability $(\mathrm{P})$ of $0.018 \geq 0.01$, meaning $\mathrm{H} 1$ is rejected. This shows that tax knowledge has no effect on taxpayers' trust. The second hypothesis $(\mathrm{H} 2)$ has a $\mathrm{CR}$ value of $2.496<2.58$ and $\mathrm{P}$ of $0.013 \geq 0.01$, meaning $\mathrm{H} 2$ is rejected. This result shows that tax complexity has no effect on taxpayers' trust. The third hypothesis (H3) has a $\mathrm{CR}$ value of $2.593 \geq 2.58$ and $\mathrm{P}$ of $0.002<0.01$, meaning $\mathrm{H} 3$ is accepted. This result shows that tax justice influences taxpayers' trust. The fourth hypothesis (H4) has a CR value of $2.521<2.58$ and P of $0.054 \geq 0.01$, meaning H4 is rejected. This result shows that tax knowledge has no effect on tax compliance. The fifth hypothesis (H5) has a CR value of $2.368<2.58$ and P of $0.059 \geq 0.01$, meaning H5 is rejected. This result illustrates that tax complexity has no effect on tax compliance. The sixth hypothesis (H6) has a CR value of 2.685 $\geq 2.58$ and $\mathrm{P}$ of $0.004<0.01$, meaning $\mathrm{H} 6$ is accepted. This result shows that tax justice influences tax compliance. The seventh hypothesis (H7) has a CR value of $5,727 \geq 2,58$ and $\mathrm{P}$ of $0.003<0.01$, meaning $\mathrm{H} 7$ is accepted. This result shows that taxpayers' trust influences tax compliance.

\subsection{Z-test analysis}

The following is the result of differences in levels of tax compliance before and after the implementation of a short message service (SMS) blast program (see Table 8).

Table 8. Differences in Individual Tax Compliance Levels Before and After the Implementation of the SMS Blast Program

\begin{tabular}{|c|c|c|c|c|}
\hline \multicolumn{4}{|c|}{ Implementation of SMS Blast } & \multirow{3}{*}{ Finding } \\
\hline \multicolumn{2}{|c|}{ Before } & \multicolumn{2}{|c|}{ After } & \\
\hline $\mathrm{x}$ & $\mu$ & $\mathrm{x}$ & $\mu$ & \\
\hline 4.31 & 5.62 & 7.09 & 8.08 & $x \neq \mu$ \\
\hline
\end{tabular}

The result of the Z-test (particularly, two-way hypotheses with SPSS as a statistical tool) shows that there are differences in tax-compliance levels after the implementation of the SMS blast program. This is because the average value of the population (x) does not equal the average sample $(\mu)$. Before the implementation of the SMS blast, the tax-compliance levels of the semi-noncompliant groups of individual taxpayers, which are a combination of PNFT and NPFT, are better than that of NPNFT. After the implementation of this program, the semi-noncompliant groups became more compliant and partly turned into compliant group PFT. Additionally, the NPNFT group became more compliant and partially converted into a semi-noncompliant group. These facts show that there are differences of tax-compliance levels after the implementation of the SMS blast and that this program is effective in increasing tax compliance in South Sumatra. Therefore, the eighth hypothesis (H8) of this research is accepted. 


\section{ENTREPRENEURSHIP AND SUSTAINABILITY ISSUES}

ISSN 2345-0282 (online) http://jssidoi.org/jesi/

2020 Volume 8 Number 2 (December)

http://doi.org/10.9770/jesi.2020.8.2(82)

Make your research more visible, join the Twitter account of ENTREPRENEURSHIP AND SUSTAINABILITY ISSUES: @Entrepr69728810

This study finds that tax knowledge does not affect taxpayers' trust. It reveals that the availability of dimensions along with indicators that form tax knowledge are not able to influence the trust of individual taxpayers. This finding corresponds to the results of Manual and Xin (2016). However, there are some important differences between the two studies, especially regarding variable indicators. "Remembering" was the strongest indicator of the tax-knowledge variable, while "tax training" was the weakest.

This research also reveals that tax knowledge has no effect on tax compliance, similar to a study by Fauziati, Minovia, Muslim, and Nasrah (2016). Based on these two findings, this study suggests that the Indonesian tax authorities need to provide more tax training to improve taxpayers' knowledge, as explained by Anderson et al. (2001). Moreover, this study shows that tax complexity does not affect the trust of individual taxpayers. This contradicts results reported by Budak and James (2018), Forest and Sheffrin (2002), and Mahangila (2017). This study also notices that tax complexity has no effect on tax compliance. In contrast, Kirchler et al. (2006) argue that the possibilility of taxpayers to comply is higher when tax laws are less complex.

This study reveals that "appropriateness of tax rates increase" and "difficulty in calculating taxable income" are the strongest indicators of tax complexity, while "overly long sentences" and the "use of difficult words in tax forms" are the weakest. This study also reveals that tax justice affects the trust of taxpayers. Similarly, Faizal and Palil (2015), who researched individual taxpayers in Malaysia, prove that the perception of tax justice impacts taxpayers' trust. In this research, "correction" was the most robust indicator of tax justice that affects taxpayers' confidence in taxes, while "criminal sanction" was the weakest. Additionally, tax justice was found to influence tax compliance. These findings support the results of Gilligan and Richardson (2005). Concerning the measures of the tax justice variable, this study notices that "consistency," "compatibility," 'correction," "respect," "appropriateness," and "tax penalties" are the most robust indicators of tax justice that affect tax compliance. Conversely, the "bias" indicator is the weakest. Furthermore, this study exhibits that taxpayers' trust influences tax compliance, similar to a study by Damayanti and Martono (2018), who utilize the slippery slope theory in their research. This present research also contributes to the findings of "obedience to the law," "trust in tax authority action," and "legal norms" as the strongest gauges of taxpayers" trust that affect tax compliance, while "sense of responsibility," "social norms," and "personal norms" are the weakest.

Finally, this study shows that there are differences in tax-compliance levels after the implementation of the SMS blast program. This is in line with that of Wardani and Wati (2018), who discovered significant differences before and after the enactment of tax counseling. This study also offers the categorisation of noncompliant registered individual taxpayers, consisting of paying-nonfiling taxpayers (PNFT), filing-nonpaying taxpayers (FNPT), and nonpaying-nonfiling taxpayers (NPNFT), as the novelty of this research. This is because none of the previous studies have focused on the differences in tax-compliance levels among individual taxpayers before and after the implementation of certain tax schemes.

\section{Conclusions}

This study has shown that tax justice and taxpayers' trust are determinants of tax compliance in South Sumatra, Indonesia. However, two other variables analyzed in this study, namely, tax knowledge and tax complexity, are proven to not influence tax compliance. The survey results also show that tax complexity has the lowest score among the variables. Therefore, tax authorities need to reassess their policies in improving tax compliance and give more attention to weak predictors of variable indicators, particularly those with the lowest scores. Additionally, this study reveals differences in tax-compliance levels after the implementation of the SMS blast program. 


\section{ENTREPRENEURSHIP AND SUSTAINABILITY ISSUES}

ISSN 2345-0282 (online) http://jssidoi.org/jesi/ 2020 Volume 8 Number 2 (December) http://doi.org/10.9770/jesi.2020.8.2(82)

Make your research more visible, join the Twitter account of ENTREPRENEURSHIP AND SUSTAINABILITY ISSUES: @Entrepr69728810

The findings of this study have three main implications. First, it provides a comprehensive review of prior research that had studied the influence of economic and noneconomic factors on tax compliance. Second, it determines which variables are significant predictors of the outcome variables. This relates to the four variables involved in this study as determinants of tax compliance: tax knowledge, tax complexity, tax justice, and taxpayers' trust. By understanding the determinants of tax compliance, the management team of tax authorities in South Sumatra will be able to find solutions to repair and upgrade the variables that have no effect on tax compliance. Third, this study delivers suggestions to the Indonesian tax authorities for improving tax compliance not only based on accelerated tax revenue but also new tax revenue generated from nonpaying-nonfiling taxpayers (NPNFT). The key direction for future research is a wider coverage of respondents to include registered and unregistered taxpayers as well as samples that capture the voice of the population and taxpayers in other regions. This will provide a more comprehensive explanation of the low tax compliance phenomenon in Indonesia.

\section{References}

Ajzen, I. (1991). The theory of planned behavior. Organizational Behaviour and Human Decision Processes, 50, $179-211$. https://doi.org/10.1016/0749-5978(91)90020-T

Alm, J. (2018). What motivates tax compliance? Journal of Economic Surveys, 33(2), 1-36. https://doi.org/10.1111/joes.12272

American Institute of Certified Public Accountants. (1992). Blueprint for tax simplification. AICPA. Reviewed September 24,2019 from https://core.ac.uk/download/pdf/147632736.pdf

Anderson, L. W., Krathwohl, D. R., Airasian, P. W., Cruikshank, K. A., Mayer, R. E., Pintrich, P. R., Raths, J. \& Wittrock, M. C. (2001). A taxonomy for learning, teaching, and assessing: A revision of Bloom's Taxonomy of educational objectives (Abridged $\mathrm{E}$; L. W. Anderson \& D. R. Krathwohl, Eds.). Longman.

Araki, S., \& Claus, I. (2014). A comparative analysis of tax administration in Asia and the Pacific. Asian Developmet Bank. Reviewed May 5, 2020 from https://core.ac.uk/download/pdf/144981435.pdf

Asrinanda, \& Diantimala, Y. (2018). The effect of tax knowledge, self assessment system, and tax awareness on taxpayer compliance. Review of Public Administration and Management, 8(10), 539-550. https://doi.org/10.6007/IJARBSS/v8-i10/4762

Bărbuţă-Mişu, N. (2011). A review of factors for tax compliance. Annals of "Dunarea de Jos" University of Galati Fascicle I. Economics and Applied Informatics Years, 17(1), 69-76. Retrieved from https://core.ac.uk/download/pdf/26692348.pdf

Belay, S. A., \& Viswanadham, P. (2016). Tax fairness perceptions and compliance behavior: Evidence from the Metropolitan Cities of the Amhara Regional State of Ethiopia. International Journal of Science and Research (IJSR), 5(4), 1173-1183. Retrieved May 9, 2020 from https://pdfs.semanticscholar.org/7b56/09b1ffd20f0d893919e8ad7f3471912b5b7f.pdf

Benk, S., Budak, T., \& Cakmak, A. (2012). Tax professionals' perceptions of tax fairness: Survey evidence in Turkey. International Journal of Business and Social Science, 3(2), 112-117. Retrieved May 9, 2020 from http://www.ijbssnet.com/journals/Vol_3_No_2_Special_Issue_January_2012/13.pdf

Bernard, O. M., Memba, F. S., \& Oluoch, O. (2018). Influence of tax knowledge and awareness on tax compliance among investors in the Export Processing Zones in Kenya. International Journal of Scientific Research and Management (IJSRM), 06(10), 728-733. https://doi.org/10.18535/ijsrm/v6i10.em01

Bird, R. M., Martinez-Vazquez, J., \& Torgler, B. (2008). Tax effort in developing countries and high income countries: The impact of corruption, voice and accountability. Economic Analysis and Policy, 38(1), 55-71. Retrieved June 21, 2020 from https://www.researchgate.net/publication/4802491_Tax_Effort_in_Developing_Countries_and_High_Income_Countries_The_Impa ct_of_Corruption_Voice_and_Accountability

Bornman, M. (2015). The determinants and measurement of trust in tax authorities as a factor influencing tax compliance behavior. Journal of Economic and Financial Sciences, 8(3), 772-789. https://doi.org/10.4102/jef.v8i3.121

Brainyyah, M. Q., \& Rusydi, M. K. (2016). The effect of tax fairness, tax knowledge, and tax complexity on tax compliance: The case of SME entrepreneurs' taxpayers in Malang. Jurnal Ilmiah Mahasiswa FEB Universitas Brawijaya, 1-17. Retrieved May 9, 2020 from https://jimfeb.ub.ac.id/index.php/jimfeb/article/view/519

Budak, T., \& James, S. (2018). The level of tax complexity: A comparative analysis between the UK and Turkey based on the OTS Index. $\begin{array}{lllllll}\text { International Tax Journal, February 27-40. Retrieved } & \text { May } & 9, & 2020 & \text { from }\end{array}$ https://www.researchgate.net/publication/323525598_The_Level_of_Tax_Complexity_A_Comparative_Analysis_Between_the_UK and Turkey Based on the OTS Index

Chau, G., \& Leung, P. (2009). A critical review of Fischer tax compliance model: A research synthesis. Journal of Accounting and Taxation, 1(2), 034-040. https://doi.org/10.5897/JAT09.021

Chin, W. W. (1998). Issues and opinion on structural equation modeling. MIS Quarterly, 22(1), 7-16. Retrieved May 9, 2020 from https://www.researchgate.net/publication/220260360_Issues_and_Opinion_on_Structural_Equation_Modeling 


\section{ENTREPRENEURSHIP AND SUSTAINABILITY ISSUES}

ISSN 2345-0282 (online) http://jssidoi.org/jesi/ 2020 Volume 8 Number 2 (December)

http://doi.org/10.9770/jesi.2020.8.2(82)

Make your research more visible, join the Twitter account of ENTREPRENEURSHIP AND SUSTAINABILITY ISSUES: @Entrepr69728810

Colquitt, J. A. (2001). On the dimensionality of organizational justice: A construct validation of a measure. Journal of Applied Psychology, 86(3), 386-400. https://doi.org/10.1037//0021-9010.86.3.386

Cox, S. P., \& Eger III, R. J. (2006). Procedural complexity of tax administration: the road fund case. Journal of Public Budgeting, Accounting \& Financial Management, 18(3), 259-283. https://doi.org/10.1108/JPBAFM-18-03-2006-B001

Damayanti, T., \& Martono, S. (2018). Taxpayer compliance, trust, and power. Jurnal Keuangan Dan Perbankan, 22(2), 231-239. https://doi.org/10.26905/jkdp.v22i2.1580

Fahr, R., \& Djawadi, B. M. (2013). The impact of tax knowledge and budget spending influence on tax compliance (IZA Discussion Paper No. 7255). Retrieved May 9, 2020 from https://papers.ssrn.com/sol3/papers.cfm?abstract_id=2234277

Faizal, S. M., \& Palil, M. R. (2015). Study on fairness and individual tax compliance in malaysia: preliminary findings. International Journal of Business, Economics and Law, 8(1), 74-79. Retrieved May 5, 2019 from http://ijbel.com/wpcontent/uploads/2016/01/Acc-35.pdf

Fajarwati, R. N., Kertahadi, \& Kurniawan, B. C. (2004). Analisis peningkatan kepatuhan wajib pajak sebelum dan sesudah penerapan modernisasi administrasi perpajakan (studi pada Kantor Pelayanan Pajak Pratama se Malang Raya). Jurnal Mahasiswa Perpajakan, 1-10. Retrieved August 23, 2020 from http://perpajakan.studentjournal.ub.ac.id/index.php/perpajakan/article/view/42/36

Farrar, J. M., Donnelly, M. E., \& Dhaliwal, S. B. (2013). Procedural aspects of tax fairness: A content analysis of Canadian tax jurisprudence. The ATA Journal of Legal Tax Research, 11(2), 21-37. https://doi.org/10.2308/jltr-50552

Forest, A., \& Sheffrin, S. M. (2002). Complexity and compliance: An empirical investigation. National Tax Journal, 55(1), 75-88. https://doi.org/10.17310/ntj.2002.1.05

Fornell, C., \& Bookstein, F. L. (1982). Two structural equation models: LISREL and PLS applied to consumer exit-voice theory. Journal of Marketing Research, 19(4), 440-452. https://doi.org/10.2307/3151718

Gambo, E.-M. J., Mas'ud, A., Nasidi, M., \& Oyewole, O. S. (2014). Tax complexity and tax compliance in African self-assessment environment. International Journal of Management Research \& Review (IJMRR), 4(5), 575-582. Retrieved May 10, 2020 from https://www.academia.edu/7339168/Tax_Complexity_and_Tax_Compliance_in_African_Self_Assessment_Environment

Gberegbe, F. B., Idornigie, G. A., \& Nkanbia-Davis, L. O. (2015). Perception of tax fairness and personal income tax compliance in Ken Saro-Wiwa Polytechnic, Bori. IOSR Journal of Economics and Finance (IOSR-JEF), 6(6), 1-11. https://doi.org/10.9790/5933$\underline{06610111}$

Gberegbe, F. B., \& Umoren, A. O. (2017). The perception of tax fairness and personal income tax compliance of Smes in Rivers State. Journal of Research in Business and Management, 5(2), 40-51. Retrieved May 5, 2019 from http://www.questjournals.org/jrbm/papers/vol5-issue2/E524051.pdf

Gilligan, G., \& Richardson, G. (2005). Perceptions of tax fairness and tax compliance in Australia and Hong Kong-A preliminary study. Journal of Financial Crime, 12(4), 331-343. https://doi.org/10.1108/13590790510624783

Gitaru, K. (2017). The effect of taxpayer education on tax compliance in Kenya (a case study of SME's in Nairobi Central Business District) (MPRA Paper 80344). Retrieved from https://mpra.ub.uni-muenchen.de/80344/

Hair, J. F., Black, W. C., Babin, B. J., \& Anderson, R. E. (2010). Multivariate data analysis (7th ed.) Pearson Education Limited.

Indonesian Directorate General of Taxes (2018). 2018 performance report. Retrieved August 22, 2020 from https://pajak.go.id/sites/default/files/2019-05/LAKIN\%20DJP\%202018.pdf

Husaini, Pirzada, K., Saiful, (2020). Risk Management, Sustainable Governance Impact on Corporate Performance. Journal of Security and Sustainability Issues, 9(3), 993-1004. https://doi.org/10.9770/jssi.2020.9.3(23)

Istiqamah, N., Herwanti, T., \& Surasni, N. K. (2018). The influence of tax knowledge, tax penaltied and internal control system on treasures' tax compliance in Bima Municipality, West Nusa Tenggara Province, Indonesia. International Journal of Economics, Commerce and Management, 6(2), 598-608. Retrieved May 10, 2020 from http://ijecm.co.uk/wp-content/uploads/2018/02/6238.pdf

Kastlunger, B., Lozza, E., Kirchler, E., \& Schabmann, A. (2013). Powerful authorities and trusting citizens: The Slippery Slope Framework and tax compliance in Italy. Journal of Economic Psychology, 34, 36-45. https://doi.org/10.1016/j.joep.2012.11.007

Kirchler, E. (2007). The Economic psychology of tax behaviour. Cambridge University Press.

Kirchler, E., Kogler, C., \& Muehlbacher, S. (2014). Cooperative tax compliance: From deterrence to deference. Current Directions in Psychological Science, 23(2), 87-92. https://doi.org/10.1177/0963721413516975

Kirchler, E., Niemirowski, A., \& Wearing, A. (2006). Shared subjective views, intent to cooperate and tax compliance: Similarities between Australian taxpayers and tax officers. Journal of Economic Psychology, 27, 502-517. https://doi.org/10.1016/j.joep.2006.01.005

Kogler, C., Batrancea, L., Nichita, A., Pantya, J., Belianin, A., \& Kirchler, E. (2013). Trust and power as determinants of tax compliance: Testing the assumptions of the slippery slope framework in Austria, Hungary, Romania and Russia. Journal of Economic Psychology, 34, 169-180. https://doi.org/10.1016/j.joep.2012.09.010

Komalasari, P. T., \& Nasih, M. (2010). Tingkat kepatuhan wajib pajak dan tarif pajak: Uji pengaruh karakteristik pendapatan. Jurnal Manajemen Teori Dan Terapan, 3(2), 112-128. https://doi.org/10.20473/jmtt.v3i2.2396

Krause, K. (2000). Tax complexity: Problem or opportunity? Public Finance Review, $28(5)$, 395-414. https://doi.org/10.1177/109114210002800501 


\section{ENTREPRENEURSHIP AND SUSTAINABILITY ISSUES}

ISSN 2345-0282 (online) http://jssidoi.org/jesi/ 2020 Volume 8 Number 2 (December)

http://doi.org/10.9770/jesi.2020.8.2(82)

Make your research more visible, join the Twitter account of ENTREPRENEURSHIP AND SUSTAINABILITY ISSUES: @Entrepr69728810

Linn, R. L., \& Grondlund, N. E. (2000). Measurement and assessment in teaching (8th ed.). Pearson Education. https://doi.org/10.1177/0734282906286619

Mahangila, D. (2017). The impact of tax compliance costs on tax compliance behaviour. Journal of Tax Administration, 3(1), 57-81. Retrieved May $\quad 15, \quad 2020 \quad$ from https://www.researchgate.net/publication/317560428_THE_IMPACT_OF_TAX_COMPLIANCE_COSTS_ON_TAX_COMPLIAN CE_BEHAVIOUR

Manual, V., \& Xin, A. Z. (2016). Impact of tax knowledge, tax compliance cost, tax deterrent tax measures towards tax compliance behavior: A survey on self-employed taxpayers in West Malaysia. Electronic Journal of Business and Management, 1(1), 56-70. $\begin{array}{lllll}\text { Retrieved } \quad \text { May } & 11, & 2020\end{array}$ http://www.apu.edu.my/ejournals/ejbm/journal/2016/Paper6 Impact of Tax Knowledge Tax Compliance Cost.pdf

McCaffery, E. J. (1990). The holy grail of tax simplification. Wisconsin Law Review, 5, 1267-1322. Retrieved May 11 , 2020 from https://heinonline.org/HOL/LandingPage?handle=hein.journals/wlr1990\&div=51\&id=\&page=

McKerchar, M. (2005). The impact of tax complexity on practitioners in Australia. Australian Tax Forum, 20(4), 529-554. Retrieved July 28, 2019 from https://heinonline.org/HOL/LandingPage?handle=hein.journals/austraxrum20\&div=17\&id=\&page=

Muehlbacher, S., Kirchler, E., \& Schwarzenberger, H. (2011). Voluntary versus enforced tax compliance: empirical evidence for the "slippery slope" framework. European Journal of Law and Economics, 32(1), 89-97. https://doi.org/10.1007/s10657-011-9236-9

Mukasa, J. (2011). Tax knowledge, perceived tax fairness and tax compliance in Uganda: The Case of Small and Medium Income Taxpayers in Kampala Central Division (Master's Thesis, Makarere University, Uganda). Retrieved May 11, 2020 from https://www.academia.edu/5619390/Tax knowledge perceived tax fairness and tax compliance in Uganda

Musthapha, B. (2010). The impact of tax fairness and demographic factors on tax compliance in Nigeria. Master's Thesis, Universiti Utara $\begin{array}{lllll}\text { Malaysia. } & \text { Retrieved } & \text { May } & 12, & 2020\end{array}$ https://www.academia.edu/1609100/The_Impact_of_Tax_Fairness_and_Demographic_Factors_on_Tax_Compliance_in_Nigeria

Najah, S. (2008). Analisis Perbedaan Tingkat Kepatuhan Wajib Pajak Badan dalam Memenuhi Kewajiban Perpajakan Sebelum dan Sesudah Tax Audit (Studi Kasus pada KPP Pratama Jakarta Tebet) (Master's Thesis, UIN Syarif Hidayatullah). Retrieved August 23, 2020 from http://repository.uinjkt.ac.id/dspace/bitstream/123456789/12902/1/SAFINATUN NAJAH-FEB.pdf

Newman, W., \& Nokhu, M. (2018). Evaluating the impact of tax knowledge on tax compliance among small medium enterprises in a developing country. Academy of Accounting and Financial Studies Journal, 22(6), 1-14. https://www.abacademies.org/articles/Evaluating-the-Impact-of-Tax-Knowledge-on-Tax-Compliance-Among-Small-MediumEnterprises-1528-2635-22-6-302.pdf

Nunnally, J. C., \& Bernstein, I. H. (1994). Psychometric theory (3rd ed.). New York, US: Mac Graw-Hill.

OECD. (2008). Globalisation and emerging economies. https://doi.org/https://dx.doi.org/10.1787/9789264044814-en

OECD. (2017). Revenue statistics in Asian countries 2017. https://doi.org/https://dx.doi.org/10.1787/9789264278943-en

Olaoye, C. O., Ayeni-Agbaje, A. R., \& Alaran-Ajewole, A. P. (2017). Tax information, administration and knowledge on taxpayers' compliance of block moulding firms in Ekiti State. Journal of Finance and Accounting, 5(4), 131-138. https://doi.org/10.11648/j.jfa.20170504.12

Palil, M. R., Akir, M. R. M., \& Ahmad, W. F. B. W. (2013). The perception of taxpayers on tax knowledge and tax education with level of tax compliance: A study the influences of religiosity. ASEAN Journal of Economics, Management and Accounting, 1(1), 118-129. Retrieved May 24, 2018 from https://fem.ipb.ac.id/miicema/e-journal/v1n1/8.pdf

Pau, C., Sawyer, A. J., \& Maples, A. (2007). Complexity of tax simplification: A New Zealand perspective. Australian Tax Forum, 22(1), 59-92. https://doi.org/10.1057/9781137478696

Richardson, G. (2006). Determinants of tax evasion: A cross-country investigation. Journal of International Accounting, Auditing and Taxation, 15(2), 150-169. https://doi.org/10.1016/j.intaccaudtax.2006.08.005

Richardson, M., \& Sawyer, A. J. (1998). Complexity in the expression of New Zealand tax laws: An empirical analysis. Australian Tax Forum, 14(3), 325-360. https://doi.org/10.1057/9781137478696

Rudyanto, A. and Pirzada, K. (2020). The role of sustainability reporting in shareholder perception of tax avoidance. Social Responsibility Journal, No. ahead-of-print. https://doi.org/10.1108/SRJ-01-2020-0022

Saad, N. (2014). Tax Knowledge, Tax Complexity and Tax Compliance: Taxpayers' View. Procedia - Social and Behavioral Sciences, 109(1), 1069-1075. https://doi.org/10.1016/j.sbspro.2013.12.590

Saw, K., \& Sawyer, A. J. (2010). Complexity of New Zealand's income tax legislation. Australian Tax Forum, 25, 213-244. Retrieved May 12, 2020 from https://heinonline.org/HOL/LandingPage?handle=hein.journals/austraxrum25\&div=12\&id=\&page=

Sidik, M. H. J., Zandi, G. R., \& Ruhoma, A. A. (2019). Examining the influence of fairness perception on tax compliance behavior the Libya individual taxpayers: The moderating tax awareness and tax complexity. Humanities \& Social Sciences Reviews, 7(2), 519525. https://doi.org/10.18510/hssr.2019.7261

Stewart, C. (2009). A multidimensional measure of professional learning communities: The development and validation of the Learning Community Culture Indicator (Doctoral dissertation, Brigham Young University, Provo, UT). $\underline{\text { https://doi.org/10.13140/2.1.4432.2246 }}$ 
ENTREPRENEURSHIP AND SUSTAINABILITY ISSUES

ISSN 2345-0282 (online) http://jssidoi.org/jesi/

2020 Volume 8 Number 2 (December)

http://doi.org/10.9770/jesi.2020.8.2(82)

Make your research more visible, join the Twitter account of ENTREPRENEURSHIP AND SUSTAINABILITY ISSUES: @Entrepr69728810

Susanto, Y. K., Pirzada, K., \& Adrianne, S. (2019). Is tax aggressiveness an indicator of earnings management? Polish Journal of Management Studies, 20 (2) 516-527. http://doi.org/10.17512/pjms.2019.20.2.43

Tavakol, M., \& Dennick, R. (2011). Making sense of Cronbach's alpha. International Journal of Medical Education, 2(1), 53-55. https://doi.org/10.5116/ijme.4dfb.8dfd

Terre, B. M., Durrheim, K., \& Painter, D. (2006). Research in practice: Applied methods for the social sciences (2nd ed.). UCT Press.

Wahl, I., Kastlunger, B., \& Kirchler, E. (2010). Trust in authorities and power to enforce tax compliance: An Empirical Analysis of the "slippery slope framework". Law \& Policy, 32(4), 383-406. https://doi.org/10.1111/j.1467-9930.2010.00327.x

Wardani, D. K., \& Wati, E. (2018). Wajib pajak dengan pengetahuan perpajakan sebagai variabel intervening (Studi pada wajib pajak orang pribadi di KPP Pratama Kebumen). Jurnal Nominal, 7(1), 22-54. Retrieved August 23, 2020 from https://journal.uny.ac.id/index.php/nominal/article/view/19358/10682

World Bank. (2019). Gross domestic product 2018. Retrieved July 27, 2019 from https://databank.worldbank.org/data/download/GDP.pdf

\section{Acknowledgements}

The authors would like to thank the anonymous reviewers for their helpful and constructive comments that greatly contributed to improving the final version of this paper. We would also like to thank the editors for their generous comments and support during the review process. Finally, we are grateful for the support of the Doctoral Program Chief and Staff at the University of Bengkulu, Bengkulu, Indonesia.

Musthafa Kemal NASUTION is a PhD candidate in management science, Faculty of Business and Economics at University of Bengkulu, Bengkulu, Indonesia. He is currently working as the head of the Tax Audit Section at the Indonesian Directorate General of Taxes. Research interests: taxation. behavioral finance.

ORCID ID: https://orcid.org/0000-0002-7337-7621

Fitri SANTI is an Associate Professor of management and finance in the Management Department, University of Bengkulu. She works at the University of Bengkulu, Faculty of Economics and Business. Research fields: banking, finance and investement, behavioral finance and corporate governance. She has published papers both in national and international journals and presented papers at various international conferences.

ORCID ID: https://orcid.org/0000-0002-2404-5604

HUSAINI is an Associate Professor of Accounting in the Accounting Department, University of Bengkulu. He works at the University of Bengkulu, Faculty of Economics and Business. Research fields: corporate governance, risk management, and auditing.

ORCID ID: https://orcid.org/0000-0001-6482-9844

FADLI is a lecturer and researcher in the Accounting Department, University of Bengkulu. He works at the University of Bengkulu, Faculty of Economics and Business. His research fields are accounting and management.

ORCID ID: https://orcid.org/0000-0001-6874-1858

Kashan PIRZADA is an Asst. Prof. of financial accounting at the Asian Research Institute for Corporate Governance (AIRCG) and Tunku Puteri Intan Safinaz School of Accountancy, Universiti Utara Malaysia. He continues researching on financial accounting issues in both advanced capitalist countries and emerging/less-developed countries.

ORCID ID: https://orcid.org/0000-0003-1186-0631

Copyright (C) 2020 by author(s) and VsI Entrepreneurship and Sustainability Center

This work is licensed under the Creative Commons Attribution International License (CC BY).

http://creativecommons.org/licenses/by/4.0/

CC) $\underset{\mathrm{EY}}{0}$ Open Access 